\title{
Informacje dla Autorów
}

Teksty należy nadsyłać w postaci wydruku (jeden egzemplarz) i w formie elektronicznej - preferowany format MS Word ${ }^{\star}$ Ami Pro* Word Perfect - $\mathrm{z}$ dołączonym oświadczeniem o oryginalności pracy oraz o tym, że nie uczestniczy ona aktualnie w innym postępowaniu wydawniczym. Prosimy o zachowanie szerokiego marginesu i podwójnej interlinii, bez wstawiania śródtytułów. Konieczne jest także umieszczenie dokładnego adresu do korespondencji oraz informacji o autorze, w której powinny być podane: tytuł naukowy, zajmowane stanowisko oraz miejsce pracy. Zostanie to wykorzystane $\mathrm{w}$ pierwszym przypisie artykułu.

Redakcja nie zwraca tekstów niezamówionych oraz zastrzega sobie prawo do ich redagowania i skracania.

Artykuł, raport z badań czy komunikat powinien liczyć do 42000 znaków, włączając abstrakty, tekst właściwy, tabele i wykresy oraz przypisy. Recenzja, glosa, opinia powinna zawierać do 15000 znaków. Sprawozdanie, nota, powinna zawierać do 10000 znaków. Abstrakt - w j. polskim i j. angielskim - do 1000 znaków; w sposób syntetyczny i klarowny powinien wskazywać cele, metody analizy oraz główne wnioski, eksponując wartość dodaną dla podjętej problematyki.

Format przypisów bibliograficznych (op.cit.; ibidem):

- $\quad$ książka - M. Weber, Etyka protestancka a duch kapitalizmu, Lublin 1993.

- $\quad$ tekst w pracy zbiorowej - J. Ł. Grzelak, Dylematy społeczne, [w:] Psychologia ekonomiczna, pod red. T. Tyszka, Gdańsk 2004, s. 265.

- $\quad$ artykuł w czasopiśmie - T. Szlendak, Techno-dzieci końca ery industrialnej, „Studia Socjologiczne” nr 1, 1994, s. 128.

- Internet, jako źródło informacji, wygrywa $z$ telewizja i prasa, www. internetstats.pl, (27.02.2010).

- powtórzenie:

- J. Kowalski, op.cit., s. 12 (gdy ponownie powoływana jest tylko jedna publikacja danego autora) 
- J. Kowalski, Zależności pomiędzy..., s. 23-34 (gdy ponownie powoływana jest jedna $\mathrm{z}$ kilku publikacji danego autora)

Autorzy w ciągu 2 tygodni od wpłynięcia tekstu są informowani o zakwalifikowaniu go do postępowania recenzyjnego lub odrzuceniu ze względu na uchybienia formalne. Następnie każda praca (po usunięciu personaliów autora) jest wysyłana recenzentowi. W ciągu 3 miesięcy autor otrzymuje konkretną decyzję odnośnie losów nadesłanego materiału.

Z uwagi na fakt tematycznego sprofilowania poszczególnych numerów kwartalnika, zakwalifikowany artykuł zostanie opublikowany zgodnie z jego merytoryczną treścią.

Na stronie internetowej czasopisma dostępne są spisy treści oraz abstrakty z kolejnych numerów kwartalnika.

Tematyka poszczególnych numerów „Przeglądu Prawa Konstytucyjnego":

- Systemy rządów w państwach europejskich;

- Teoria a praktyka konstytucyjna w państwach europejskich;

- Instytucje ustrojowe w państwach europejskich;

- Władza sądownicza w państwach europejskich;

- Podziały władzy w państwach europejskich;

- Deficyt demokracji czy legitymacji - monarchie i republiki europejskie;

- Recepcja instytucji konstytucyjnych w Europie;

- Konstytucyjne aspekty funkcjonowania mediów w Europie;

- Prawa i wolności socjalne, ekonomiczne i kulturalne w państwach europejskich.

Adres poczty elektronicznej: ppk@marszalek.com.pl Adres strony internetowej: http://www.marszalek.com.pl/przegladprawakonstytucyjnego/index.html 


\section{Guidelines for Authors}

Authors should submit MS Word ${ }^{\star}$ AmiPro* Word Perfect files and one copy of the manuscript with enclosed statement of originality and a statement that it is not under consideration for publication process elsewhere. Please keep the wide margin and double leading, without caption. It is important to provide address for mail, information about the Author (academic degree, position and place of work). This information will be used in the first footnote in the article.

We do not return not ordered texts and we reserve the right to their editing and shortening.

Article, research report or communicate should have up to 42000 characters, including abstracts, main text, tables, diagrams and footnotes. Review, glossaries, opinion should have up to 15000 characters; report and note up to 10000 characters. Abstract - in Polish and English - up to 1000 ; it should clearly explain the aim and methods of analysis and conclusions, presenting the value of the subject undertaken.

Format of bibliography (op.cit.; ibidem):

- book - M. Weber, Etyka protestancka a duch kapitalizmu, Lublin 1993.

- $\quad$ an article in a collective work - J. Ł. Grzelak, Dylematy społeczne, [w:] Psychologia ekonomiczna, pod red. T. Tysza, Gdańsk 2004, s. 265.

- $\quad$ an article in a journal - T. Szlendak, Techno-dzieci końca ery industrialnej, „Studia Socjologiczne” nr 1, 1994, s. 128.

- the Internet - Internet jako źródło informacji, wygrywa z telewizja i prasa, www.internetstats.pl, (27.02.2010).

- repetition:

- J. Kowalski, op.cit., s. 12 (when only one work of this author is cited in the paper)

- J. Kowalski, Zależności pomiędzy..., s. 23-34 (when more than one work of this author is cited in the paper) 
Authors are informed if the text has been qualified to reviewing process or rejected due to infringement of regulations within 2 weeks after submitting the file. Next, each work (after deleting Author's personal data) is sent to the reviewer. Within 3 months Author is informed about the decision concerning his work. Due to thematically profiled issues of the quarterly, the articles that have been qualified will be published according to its contents.

Table of contents and abstracts from the next issues are available on our website.

Subject matter of the particular issues of „Przegląd Prawa Konstytucyjnego":

- systems of governments in European countries;

- constitutional theory and practice in European countries;

- constitutional institutions in European countries;

- the judicial system in European countries;

- power sharing in European countries;

- democracy deficit or legitimacy deficit - monarchies and republics of Europe;

- reception of constitutional institutions in Europe;

- constitutional aspects of media functioning in Europe;

- social, economic, cultural rights and freedoms in European countries.

e-mail:ppk@marszalek.com.pl

Website: www.marszalek.com.pl/przegladprawakonstytucyjengo 